\title{
DETERMINATION OF FACTORS AFFECTING INVESTMENT PRIVALOVS LAND CITIES
}

\section{ВИЗНАЧЕННЯ ФАКТОРІВ, ЩО ВПЛИВАЮТЬ НА ПРИВАБЛИВІСЬ ЗЕМЕЛЬ МІСТ}

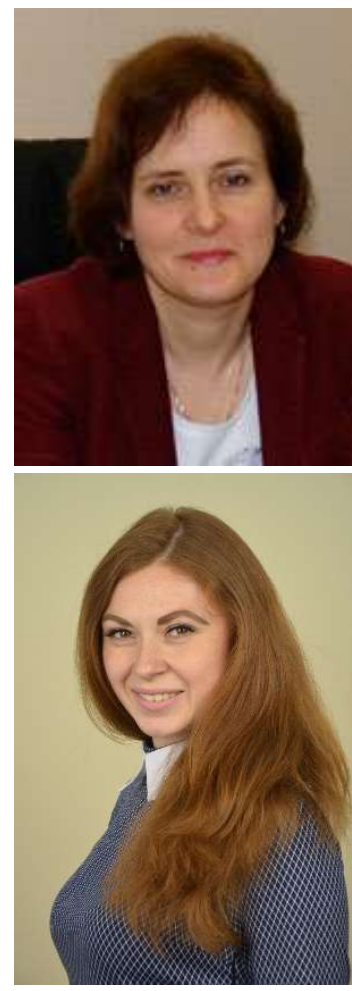

Slavinska Olena Serhiyivna, Doctor of Technical Sciences, Professor, National Transport University, Professor of the department of Transport construction and property management, e-mail: elenaslavin9@gmail.com, tel.: +380509698109, Ukraine, 01010, Kyiv, Omelyanovicha-Pavlenko str., 1

http://orcid.org/0000-0002-9709-0078

Radzinska Yuliya Borysivna, senior lecturer, O. M. Beketov National University of Urban Economy in Kharkiv, senior lecturer department of land administration and GIS, e-mail: radzinskayayb@gmail.com,tel.:+380977780307, Ukraine, 61002 Kharkiv, Marshal Bazhanov str, 17

http://orcid.org/0000-0002-1661-7975

Summary. The aim of the article is identification of main factors influencing investment attractiveness of land in the cities of Ukraine.

To achieve this goal the following tasks: determining trends and key factors in land use of cities; characteristics of land; the definition of urban areas and limitations in their use. Improved classification of the factors which allows for cartographic provision of land in cities and their investment potential, level of interaction between different stakeholder groups, areas of urban development, which allows to generate methodical toolkit for estimation of the level of investment attractiveness of land in cities.

Define the factors and features of their influence on investment processes in the sphere of land use of cities of Ukraine.

Prospects of further research is to develop a methodological approach to the evaluation of the level of investment attractiveness of land in cities and substantiation of measures on the increase of efficiency of their use.

Key words: land relations, factors of influence, investment attractiveness of the lands of restrictive factors of land use.

Introduction. Modern features and trends in urban land development require new grounded approaches to determine the factors that affect them, first and foremost, investment attractiveness, which will enable their rapid development in the overall system of city development.

Analysis of recent research and publications 
In the writings of foreign and domestic authors, much attention is paid to the study of many issues of rational use of land resources by attracting investment. In previous studies [1-4] and the existing regulatory framework [5,6] there is no consistent and unambiguous classification of factors that affect the land of cities and create their attractive features for an investor.

Purpose and tasks of the article. The aim of the article is to determine the main factors influencing the investment attractiveness of Ukrainian cities.

To achieve this goal, the following tasks are addressed:

- $\quad$ determining the directions and main factors in the field of land use of cities;

- $\quad$ characteristics of the land of cities;

- $\quad$ definition of city territories and restrictions on their use.

Materials and Methods. The city is an open, hierarchical organized economic system. The city is considered an open economic system, since the amount of resources that it receives in monetary terms is not equal to the value of products (services) that are given to them in the environment. At the same time, the city is a hierarchically organized system, as it has management bodies. The city is a special economic system, which, on the one hand, can be considered as a territory, and on the other hand, as an object of management (Fig. 1).

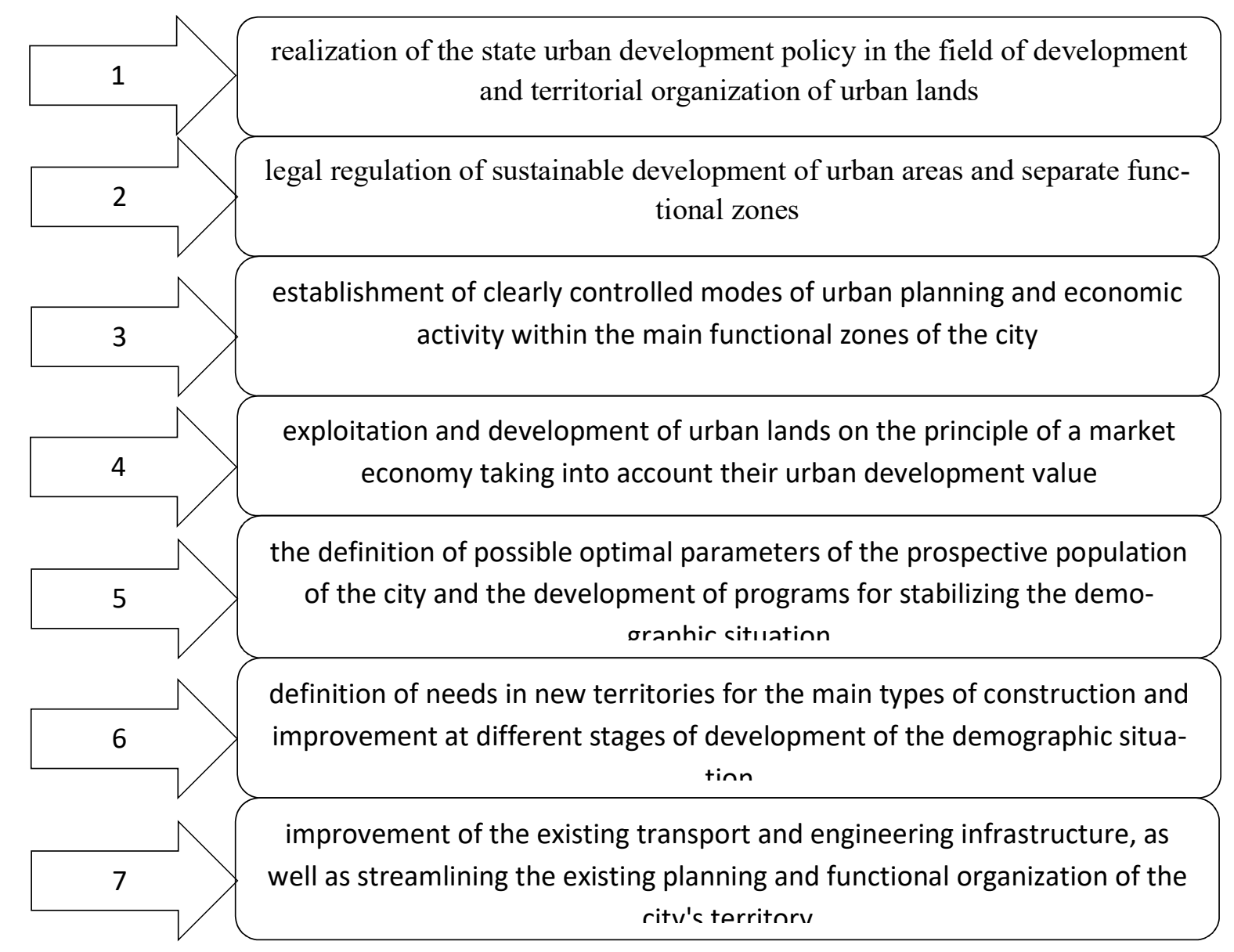

Figure 1 - Scheme of organization of the city's land

Рисунок 1 - Схема організації земель міста 
Land of the territory of the city has its own investment potential (the sum of objective prerequisites for investments, which depend on the availability and diversity of spheres and objects of investment, and on their investment attractiveness).

Not only the data on all land, buildings and structures within the city territory, qualitative characteristics and cost of reproduction, the share of improvements in urban land (engineering, transport infrastructure, etc.) should be used as the initial information for mass evaluation of urban land and real estate., usefulness of location, transport accessibility, ecology of separate sections of the city territory, information about the existence of restrictions on urban land, but also information on urban development characteristics, and the investment potential of the city's territory, etc. [4]. Consequently, at the level of a particular site, when determining its investment attractiveness for the purposes of mass assessment, it is necessary to take into account the potential increase in the benefits from the use of plots in the territories planned for development, including when changing their functional purpose, that is, in monetary terms, assess the return on the most efficient use of land Plots with the planned functional purpose and the planned level of development of infrastructure, business, etc. on this site [2].

Investment value - the value of a land plot for a particular investor. Unlike the market value, which implies the presence of a "typical" buyer or "typical" investor, the investment value is determined by the needs and characteristics of a particular person. The investment value is related to the current value of future income derived from the use of property. For an investor, such factors as risk, scale and cost of financing, the future increase or decrease in the cost of objects, changes in tax legislation are important.

When taking into account the above-mentioned vision of the relationship of factors and their impact on the value of land, a system of factors is proposed that directly affects the change in the investment attractiveness of urban lands (Table 1).

The value of urban lands depends on many factors. Without their classification, the establishment of significance, the degree of influence on the size of the fee for land, it is impossible to correctly carry out an economic assessment of the lands that are part of the city boundary.

Results and Discussion. On the other hand, an algorithm for accounting for the investment attractiveness of urban land for their mass evaluation is proposed. It consists of the following steps:

1. General strategic priorities of city development:

- strategy of social and economic development of the city;

- general development plan of the city.

2. Strategy of realization of investment potential of the city, which determines long-term plans for realization of potential of territories, list and contents of ways of their realization on the basis of strategic priorities of city development.

3. Mass evaluation of urban lands:

- definition of investment attractiveness of typical sections of the city at the moment;

- estimation of investment attractiveness of typical areas of the city in the future, as a result of the implementation of the strategy of determining the investment potential of the city.

4. Comparison of the current and planned level of investment attractiveness of land taking into account investment risks, which include the influence of factors that impede the implementation of strategic city development plans.

5. Determination of the value of the coefficient of investment attractiveness of typical sections of the city.

6. Calculation of the cost of typical land plots using the coefficient of investment attractiveness. 
Table 1 - Classification of factors characterizing the investment attractiveness of urban land [3 - 5]

Таблиця 1 - Класифікація факторів, які характеризують інвестиційну привабливість міських земель [3 - 5]

\begin{tabular}{|c|c|}
\hline Factor Name & Factor Components \\
\hline \multicolumn{2}{|r|}{ The attractiveness of the environment, the region, the market } \\
\hline $\begin{array}{l}\text { Situation in the real } \\
\text { estate market }\end{array}$ & $\begin{array}{l}\text { The ratio of demand and supply from potential tenants and lessors, sellers and } \\
\text { buyers of real estate, the marketing period of objects, the level of development } \\
\text { of firms to provide services in real estate transactions and the cost of services. }\end{array}$ \\
\hline Terms of land use & Rights to the land plot, payment for the land plot. \\
\hline $\begin{array}{l}\text { Administrative } \\
\text { regulation }\end{array}$ & Town-planning system, real estate taxes, activity of various controlling bodies. \\
\hline economic & $\begin{array}{l}\text { Investment attractiveness of the region, city, trends of industry and services, } \\
\text { solvency of enterprises and organizations. }\end{array}$ \\
\hline Socio-political situation & $\begin{array}{l}\text { Trends in changes in population size, migration, style and living standards of } \\
\text { the population (education, employment, income), crime rate, political stability. }\end{array}$ \\
\hline Natural factors & $\begin{array}{l}\text { Ecological situation, degree of propensity of the territory destructive natural } \\
\text { and anthropogenic influence. }\end{array}$ \\
\hline \multicolumn{2}{|r|}{ The attractiveness of the immediate surroundings } \\
\hline $\begin{array}{l}\text { Characteristics of the } \\
\text { location }\end{array}$ & $\begin{array}{l}\text { Distance to the city center or district, proximity to the specified objects, the } \\
\text { possibility of integrated use. }\end{array}$ \\
\hline $\begin{array}{l}\text { Degree of development } \\
\text { of the district and } \\
\text { neighboring objects }\end{array}$ & $\begin{array}{l}\text { The social and public significance of the district, existing buildings or premises } \\
\text { in the area and immediate surroundings of the land, production and social } \\
\text { infrastructure. }\end{array}$ \\
\hline Transport infrastructure & Communication with motorways, roads, public transport. \\
\hline $\begin{array}{l}\text { Engineering } \\
\text { Infrastructure }\end{array}$ & $\begin{array}{l}\text { Provision of all types of utilities, telecommunications, working conditions and } \\
\text { the degree of monopoly of organizations serving engineering systems, utility } \\
\text { costs. }\end{array}$ \\
\hline $\begin{array}{l}\text { Engineering-geological } \\
\text { conditions }\end{array}$ & $\begin{array}{l}\text { Bearing ability of soils, possibility of flooding, waterlogging, high standing of } \\
\text { groundwater. }\end{array}$ \\
\hline \multicolumn{2}{|r|}{ The attractiveness of the adjacent territories and the site itself } \\
\hline Physical characteristics & $\begin{array}{l}\text { The presence of buildings on the plot, the area and shape of the plot, its } \\
\text { condition and order, the density of development, the possibility of expansion } \\
\text { of development by acquisition of neighboring areas. }\end{array}$ \\
\hline Access to the plot & Availability and condition of access roads, parking, railway entrance. \\
\hline Legal support & $\begin{array}{l}\text { The documents certifying the rights to the land plot, possible arrest by the } \\
\text { munition, registered easements, restrictions on the use of the site. }\end{array}$ \\
\hline
\end{tabular}

These factors are systematized in three levels (Fig. 2). 


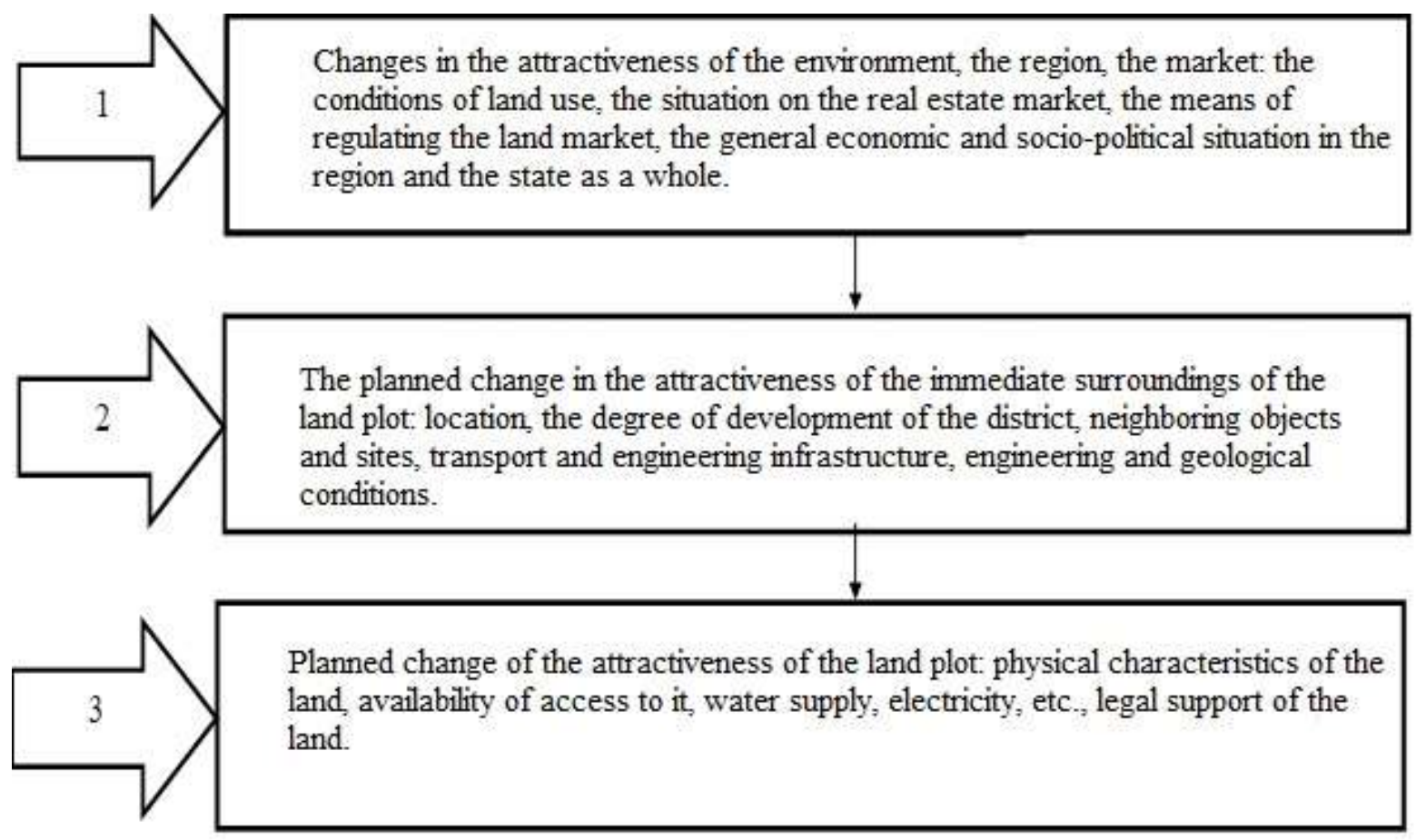

Figure 2 - Levels of systematization of factors influencing the investment attractiveness of urban land in the future

Рисунок 2 - Рівні систематизації факторів, що впливають на інвестиційну привабливість міських земель в майбутньому

On the basis of the analysis and taking into account market requirements, a general scheme for the implementation of urban land in the context of the impact on it of the factors of the external and internal environment, taking into account the investment attractiveness of urban lands by their mass assessment (Table 2).

Thus, based on the analysis of the existing experience of mass assessment of urban lands and the development of the idea of forming a method for accounting the investment attractiveness of urban lands for their mass assessment, it is proposed, for the purpose of determining the degree of expressiveness of the investment attractiveness of typical sites in the mass assessment of urban land, to assess the following characteristics of land: location ; market demand; financial feasibility (the ability of the project to invest in this area to ensure the profit from its use, sufficient to compensate investors for costs and ensure the receipt of expected profits); legal status and availability of necessary documents; maximum profitability with the most effective use of the site.

The listed characteristics assume an estimation when forming the investment value of land plots, which objectively reflects the investment potential of land plots. An important aspect in this case is precisely the accounting of the dynamics of changes in the value of land [5].

This system involves the calculation of the amount of additional benefits to the city from the implementation of investment-attractive areas by comparing the investment value of sites with the cadastral value, calculated on the basis of assessing the level of land rent for tax purposes. This benefit is formally expressed by the current level of investment attractiveness. 
Table 2 - Implementation of urban land by levels, which are formed on the basis of mass estimation using the coefficient of investment attractiveness

Таблиця 2 - Реалізація міських земель за рівнями, які формуються на основі масової оцінки із застосуванням коефіцієнта інвестиційної привабливості

\begin{tabular}{|l|l|}
\hline Level of investment program & $\begin{array}{l}\text { Type of mass estimation of urban lands according to } \\
\text { existing methods using the coefficient of investment } \\
\text { attractiveness }\end{array}$ \\
\hline Investment programs of the state level & $\begin{array}{l}\text { Formation of the cost of land in the city, taking into } \\
\text { account their investment attractiveness, demand and } \\
\text { supply analysis }\end{array}$ \\
\hline Investment proposals of the city level & $\begin{array}{l}\text { Investors selection (tenders, contests, auctions, sub- } \\
\text { contracting) }\end{array}$ \\
\hline Control of target use of the budget & $\begin{array}{l}\text { Investment development (realization of investment } \\
\text { projects) }\end{array}$ \\
\hline Results of cadastral assessment of urban lands & $\begin{array}{l}\text { Monitoring of the effectiveness of urban land imple- } \\
\text { mentation }\end{array}$ \\
\hline
\end{tabular}

Conclusions and Recommendations. As a result of the analysis it is determined that the investment attractiveness of the land of cities is formed on the basis of the combination of factors. For a comprehensive analysis of investment attractiveness, factors are identified which can not be modified in the short term and the system of factors that change over a relatively short period of time and significantly influences decision-making on the use of urban land.

The classification of factors based on the definition of geospatial land provision of cities, their investment potential, the level of interaction between different groups of interested persons, directions of urban development, has been improved, which allows us to form a methodical toolkit for an integrated assessment of the level of investment attractiveness of land in cities.

Prospects for further research are the development of a methodical approach to assessing the level of investment attractiveness of land in cities and justifying measures in relation to increasing the efficiency of their use.

\section{References}

1. Drych, A. (2010). Osnovni sposoby dosyahnennya investytsiynoyi pryvablyvosti Ukrayiny [Basic ways to achieve investment attractiveness of Ukraine], Visnyk NBU - Bulletin of the NBU, 4, 40-41 [in Ukrainian].

2. Ivanova, N. Y., Danyliv, A. I. (2006). Otsinka investytsiynoyi pryvablyvosti rehionu: porivnyal'nyy analiz suchasnykh metodyk [Assessment of the investment attractiveness of the region: a comparative analysis of modern techniques], Naukovi zapysky - Scientific Notes, 56, 16-22 [in Ukrainian].

3. Butko, M., Zelens'kyy, S., Akymenko, O. (2008). Suchasna problematyka otsinky investytsiynoyi pryvablyvosti rehionu[Modern issues of evaluation of investment attractiveness of the region], Ekonomika Ukrayiny - Economy of Ukraine, 11, 30 - 35 [in Ukrainian].

4. Ho, S., Rajabifard, A., Stoter, J., Kalantari, M. (2013). Legal barriers to 3D cadastre implementation: What is the issue?, Land Use Policy, 35, 1, 379-387 [in English].

5. Oosterom, P. (2013). Research and development in 3D cadastres, Environment and Urban Systems, 40, 1, 1-6 [in English].

6. Pro zemleustriy: Zakon Ukrayiny vid 22.05.2003 r. № 858-IV. Data onovlennya: 01.01.2016. [About the land system: Law of Ukraine dated May 22, 2003 No. 858-IV. Date updated: 01/01/2016], Available at: http://zakon2.rada.gov.ua/laws/show/858-15 [in Ukrainian]. 
7. Pro zatverdzhennya Poryadku vedennya Derzhavnoho zemel'noho kadastru: postanova Kab. Ministriv Ukrayiny vid 17.10.2012 r. № 1051 [On approval of the Procedure for maintaining the State Land Cadastre: Decree Cabinet of the Ministers of Ukraine dated 17.10.2012 № 1051] Available at: http://zakon1.rada.gov.ua/laws/show/1051-2012-p [in Ukrainian].

\section{ВИЗНАЧЕННЯ ФАКТОРІВ, ЩО ВПЛИВАЮТЬ НА ПРИВАБЛИВІСЬ ЗЕМЕЛЬ МІСТ}

Славінська Олена Сергіївна, доктор технічних наук, професор, Національний транспортний університет, професор кафедри транпортного будівництва та управління майном, e-mail: elenaslavin9@gmail.com, тел.: +380509698109, Україна, 01010, Київ, вул. Омеляновича-Павленка 1, http://orcid.org/0000-0002-9709-0078.

Радзінська Юлія Борисівна, старший викладач, Харківський національний університет міського господарства імені О.М. Бекетова, старший викладач кафедри земельного адміністрування та геоінформаційних систем, e-mail: radzinskayayb@gmail.com, тел.: +380977780307, Україна, 61002, Харків, вул. Маршала Бажанова, 17, http://orcid.org/0000-0002-1661-7975.

Анотація. Метою статті $є$ виявлення основних факторів, що впливають на інвестиційну привабливість землі в містах України.

Для досягнення цієї мети вирішуються наступні завдання: визначення тенденцій і ключових факторів в землекористуванні міст; характеристики земель; визначення міських територій та обмежень у їх використанні. Покращена класифікація факторів, що дозволяють здійснювати картографічне забезпечення земель в містах і їх інвестиційний потенціал, рівень взаємодії між різними групами зацікавлених сторін, напрямки міського розвитку, що дозволяє сформувати методичний інструментарій для оцінки рівня інвестиційної привабливості земель в містах.

Визначити фактори і особливості їх впливу на інвестиційні процеси в сфері землекористування міст України.

Перспектива подальших досліджень полягає в розробці методологічного підходу до оцінки рівня інвестиційної привабливості земель в містах і обгрунтуванні заходів щодо підвищення ефективності їх використання.

Ключові слова: земельні відносини, фактори впливу, інвестиційна привабливість земель, обмежувальні чинники, використання земель.

\section{Перелік посилань}

1. Дрич А. / Основні способи досягнення інвестиційної привабливості України. - Вісник НБУ. 2010, - № 4. - c. 40-41.

2. Іванова Н. Ю. Оцінка інвестиційної привабливості регіону: порівняльний аналіз сучасних методик / Н.Ю. Іванова, А.І. Данилів // Наукові записки. - 2006. - Т 56. - С. 16-22.

3. Бутко М. Сучасна проблематика оцінки інвестиційної привабливості регіону //М. Бутко, С. Зеленський, О. Акименко // Економіка України. - 2008. - № 11. - С. 30 - 35.

4. Ho S., Rajabifard A., Stoter J., Kalantari M. Legal barriers to 3D cadastre implementation: What is the issue? [Text] / S. Ho, A. Rajabifard, J. Stoter, M. Kalantari // Land Use Policy. 2013. - Vol. 35, N. 1. - P. 379-387.

5. Oosterom P. Research and development in 3D cadastres [Text] / P. Oosterom // Environment and Urban Systems. 2013. - Vol. 40, N. 1. - P. 1-6.

6. Про землеустрій: Закон України від 22.05.2003 p. № 858-IV. Дата оновлення: 01.01.2016. URL: http://zakon2.rada.gov.ua/laws/show/858-15.

7. Про затвердження Порядку ведення Державного земельного кадастру: постанова Каб. Міністрів України від 17.10.2012 р. № 1051. URL: http://zakon1.rada.gov.ua/laws/show/1051-2012-п. 